Omni-Akuatika, 14 (2): 43-51,2018
ISSN: 1858-3873 print / 2476-9347 online
Research Article
journal homepage: http://ojs.omniaquatika.net

\title{
Phytoremediation of Eel (Anguilla bicolor bicolor) rearing wastewater using amazon sword (Echinodorus amazonicus) and water jasmine (Echinodorus palaefolius)
}

\author{
Hany Handajani ${ }^{1,2}$, Widanarni ${ }^{3}$, Tatag Budiardi ${ }^{3}$, Mia Setiawati $^{3}$, Sujono $^{4}$ \\ ${ }^{1}$ Department of Fisheries, Faculty of Agriculture and Animal Science, University of Muhammadiyah Malang, \\ J. Raya Tlogomas No.246, Malang, 65144, Indonesia \\ ${ }^{2}$ Study Program of Aquaculture Science, Graduate School, Bogor Agricultural University, \\ Jl. Raya Darnaga, Bogor, 16680, Indonesia \\ ${ }^{3}$ Department of Aquaculture, Faculty of Fisheries and Marine Science, Bogor Agricultural University, \\ Jl. Raya Darnaga, Bogor 16680, Indonesia \\ ${ }^{4}$ Department of Animal Science, Faculty of Agriculture and Animal Science, University of Muhammadiyah Malang \\ Jl. Raya Tlogomas No.246, Malang, 65144, Indonesia \\ *Corresponding author: widanarni@yahoo.com
}

\begin{abstract}
Management of aquaculture wastewater is still the major problems in fisheries, especially in intensive systems. Intensively aquaculture activities often increase organic matter and nutrients $(N$ and $P)$ in the water. The study was conducted to evaluate the phytoremediator performance of Echinodorus amazonicus and Echinodorus palaefolius in removing inorganic nitrogen and orthophosphate from aquaculture wastewater with the recirculation system. This study used a completely randomized design with three treatments and 3 replications. The treatments of this study were P1: E. amazonicus, P2: E. palaefolius and P3: control (without aquatic plants). The tested fish were elvers which average weight $6.98 \pm 0.19 \mathrm{~g}$, and fish density was $4 \mathrm{gL}^{-1}$. Elvers reared in an aquarium that containing $48 \mathrm{~L}$ in a recirculation system. The paste feed which protein level of $45.25 \%$ was given at satiation 3 times/day. Elvers reared for 60 days. The results showed that $E$. palaefolius significantly reduced concentrations of total ammonia nitrogen (TAN), nitrite $\left(\mathrm{NO}_{2}\right)$, nitrate $\left(\mathrm{NO}_{3}\right)$ and orthophosphate $\left(\mathrm{PO}_{4}\right)$ with an efficiency of $27.10 \pm 2.42 \%$; $45.03 \pm 9.77 \%$; $20.94 \pm 1.29 \%$ and $14.19 \pm 3.05 \%$, respectively higher than $E$. amazonicus and control. The best result of elver's performance (SGR and FCR) was in treatment P2 (E. palaefolius), i.e. $1.19 \pm 0.18 \%$ and $1.57 \pm 0.30$. Based on the results of this study, it can be concluded that the use of $E$. palaefolius as phytoremediator in eel culture with recirculation system can removed inorganic nitrogen and orthophosphate more optimal compared to other treatment.
\end{abstract}

Keywords: aquaculture wastewater, nutrient removal, phytoremediation, Echinodorus amazonicus, Echinodorus palaefolius

\section{Introduction}

Increasing freshwater fish production could be achieved through intensificationor increase in fish density per unit area of culture tank. High stocking density in intensive fish culture leads to the high quantity of feed given to fish thus results in accumulation of organic matter in fish tank. Accumulation of organic matter causes the formation of toxic compounds for fish, nutrient mineralization from organic matter and high absorption of oxygen, which further decreases the water quality and creates the negative impact on fish health and production. Waste accumulation may lead to declining water quality that affects the physiological process, behavior, growth, and mortality of fish (Bureau and Hua 2011; Davidson et al. 2013; Davidson et al. 2016). Similarly,eel culture production continues to be further increased through intensification to meet the demand of the consumer.

Conventional water quality management can be done through periodic water exchange, yet it is less effective, costly, and requires quite huge amount of water. One of themanagement efforts to improve water quality and optimize the use of fish culture water can be done by performing phytoremediation technology through recirculation. Wastewater from fish 
culture that contains organic matter will decompose into inorganic materials that can be used by plants as nutrient for growth (Effendi et al. 2015). The principle of the recirculating system is the reuse of water that has been removed from aquaculture activity. Recirculating system provides benefits since it is able to minimize water use, function as $\mathrm{pH}$ buffer, and reduce organic matters like ammonia and nitrite (Suzuki et al. 2003).

The result of study performed by Brune et al. (2003) showed that about $25 \%$ of total nitrogen in feed given to fish is used for growth, while $60 \%$ of it is released in the form of $\mathrm{NH}_{3}$ and $15 \%$ of it is released in the form of feces. Therefore, the potential of ammonia waste enters fish culture water amounted to $75 \%$ of feed nitrogen. Approximately $70-80 \%$ of nitrogen in nitrogen in transformed into ammonia, both through direct excretion and mineralization by bacteria. Around $33 \%$ of nitrogen contains in fish diet will be excreted by fish and can be recycled (Crab et al. 2007).

Phytoremediation is the use of plants to decrease, extract, or remove organic and inorganic compounds from waste. The advantage of phytoremediation compared to other waste treatment technology includes the natural process, lower cost, organic matter reduction, the synergy between plants, cultured fish, and environment, and does not require high technology (Paz-Alberto and Sigua, 2013). Several previous studies had performed phytoremediation on waste from freshwater fish culture using aquatic plants such as water hyacinth (Syahputra 2005), Pistia stratiotes (Herniwati et al. 2013, Madhurina et al. 2014), Hydrilla verticilata (Rahman et al. 2011) and Lemna perpusilla (Mkandawire et al. 2007, Crishmada \& Mardiyati 2011). Application of system which combines recirculation and phytoremediator (plant with the ability to assimilate $\mathrm{N}$ and $\mathrm{P}$ nutrient produced from biofilter) results inless water use and water quality that remains good. Yet, phytoremediator commonly used is still vegetable plant like water spinach, spinach, and tomato (Ebeling et al, 2006). This phytoremediator is technically useful but economically provides relatively less benefit due to the low price of vegetable product. Hence, it is necessary to find other phytoremediators, which is able to improve the water quality of culture media besides having quite high economic value, such as freshwater aquarium plant.

\section{Materilas and Methods}

Tank preparation

The tanks used in this study were 18 rectangular aquaria at a size of $60 \times 40 \times 40 \mathrm{~cm}$. the recirculating system was designed with the water height of $25 \mathrm{~cm}$. Considering the aquatic plants, double bottom technic was applied at the bottom of aquarium with bottom layer consisted of a series of: PVC pipe as cantilever, fine gauze, dacron as filter, and sand as planting media for aquatic plant. In this research, no water exchange was applied, yet the addition of water was done to maintain the height of water level in aquarium which continued to decrease due to evaporation.

\section{Experimental fish and plant}

Fishused in this study were eels (Anguilla bicolor bicolor) with an average weight of $6.98 \pm 0.19 \mathrm{gfish}^{-1}$. Eels were obtained from eel farmer in Tulungagung. Prior to treatment, eels were adapted in fiber tank at a size of $100 \times 100 \times 100 \mathrm{~cm}$ for 30 days. The stocking density of elver was $4 \mathrm{gL}^{-1}$ (Harianto et al, 2017). Eels were maintained for 60 days. During culture, eels were fed paste feed with dietary protein (45.15\%) (Handajani et al, 2018) to at satiation. Feeding frequency was three (3) timesa day, namely in the morning (07.00), at noon (13.00) and in the afternoon (19.00) (Affandiet al 2013). Aquatic plant density in each aquarium was 80 gram (Akinbile \& Yusoff, 2012). Freshwater aquarium plantsused as phytoremediators were Echinodorus amazonicus andEchinodorus palaefolius. These plants were collected from freshwater aquarium plants in the region of Batu-Malang. Before treatment, the plants were adapted in fiber tank of $150 \times 50 \times 50 \mathrm{~cm}$ in a flow-through system for 14 days.

\section{Experimental design and data analysis}

The research was done by experimental method in the laboratory. The experimental design used completely randomized design (CRD). This research consisted of three (3) treatments, namely P1: Echinodorus amazonicus, P2: Echinodorus palaefolius, and P3: without aquatic plants. Three replications were applied in each treatment. To determine the effect of treatment on each parameter tested, ANOVA and F-test were performed using the program of SPSS ver.21 at confidence level of $95 \%$, and further followed by Tukey Multiple Range test.

\section{Data collection}

Before treatment, the measurement of water quality included the parameter of:temperature, $\mathrm{pH}$, DO, alkalinity, TSS, TAN nitrate $\left(\mathrm{NO}_{3}\right)$, 
nitrite $\left(\mathrm{NO}_{2}\right)$, and orthophosphat $\left(\mathrm{PO}_{4}\right)$. Water quality measurement was done for 60 days (2 months) after aquatic plants were put in the system. The parameter of water quality that were measured daily consisted of $\mathrm{NO}_{3}, \mathrm{NO}_{2}$, $\mathrm{PO}_{4}$, and TSS were measured twice a week (14 days) (Muangkeow et al, 2007). Measurement of TAN, nitrite, nitrate, and orthophosphate was conducted using spectrophotometer which referred to the method of APHA (2006). Water quality was measured in the laboratory of water quality and proximate analysis was performed in the laboratory of fish nutrition University of Muhammadiyah Malang.

To investigate the growth performance of eel, calculation of survival rate, SGR, feed conversion, protein retention and lipid retention was performed.

The calculation of nutrient removal was done every two weeks, include TAN, NO2, NO3, PO4 (Endut et al 2011). Measurement of aquatic plant parameter was wet biomass weight, at the beginning and the end of the research.

Nutrient removal

During the experiment, nutrient removal within the water occurred. The amount or quantity of nutrient removal can be calculated using the formula as follows (Zhou et al. 2006):

Removal efficiency $(\%)=\frac{(\mathrm{Na}-\mathrm{Nb})}{\mathrm{Ca}} \times 100$

Description:

$\mathrm{Na}=$ nutrient concentration in influent $\left(\mathrm{mgL}^{-1}\right)$

$\mathrm{Nb}=$ nutrient concentration in effluent $\left(\mathrm{mgL}^{-1}\right)$

\section{Results and Discussion}

\section{Water quality and Nutrient removal}

Results of water quality measurement during culture period (60 days) which included temperature, $\mathrm{pH}$, dissolved oxygen, alkalinity, TSS, TAN, $\mathrm{NO}_{2}, \mathrm{NO}_{3}$ and $\mathrm{PO}_{4}$ are presented in Table1.

Table 1. Water quality during culture period (60 days)

\begin{tabular}{cccc}
\hline Parameter & P1 (E. amazonicus) & P2 (E. palaefolius) & P3 (without plant) \\
\hline Temperature $\left.{ }^{0} \mathrm{C}\right)$ & $28.5-30.0$ & $29.0-30.5$ & $28.5-29.5$ \\
$\mathrm{pH}$ & $7.1-7.5$ & $7.2-7.5$ & $7.0-7.8$ \\
$\mathrm{DO}\left(\mathrm{mg} \mathrm{L}^{-1}\right)$ & $4.5-5.9$ & $4.5-6.1$ & $4.3-5.8$ \\
Alkalinity $\left(\mathrm{mg} \mathrm{L}^{-1}\right)$ & $46-105$ & $58-104$ & $60-100$ \\
$\mathrm{TSS}\left(\mathrm{mg} \mathrm{L}^{-1}\right)$ & $1.44-2.54$ & $1.2-1.98$ & $2.18-3.98$ \\
$\mathrm{TAN}\left(\mathrm{mg} \mathrm{L}^{-1}\right)$ & $0.12-0.23$ & $0.12-0.22$ & $0.13-0.23$ \\
$\mathrm{NO}_{2}\left(\mathrm{mg} \mathrm{L}^{-1}\right)$ & $0.011-0.073$ & $0.013-0.067$ & $0.013-0.089$ \\
$\mathrm{NO}_{3}\left(\mathrm{mg} \mathrm{L}^{-1}\right)$ & $15.27-49.15$ & $13.31-48.29$ & $26.71-53.14$ \\
$\mathrm{PO}_{4}\left(\mathrm{mg} \mathrm{L}^{-1}\right)$ & $1.13-7.72$ & $1.07-5.68$ & $1.39-8.79$ \\
\hline
\end{tabular}

Culture of eel using phytoremediation technology is strongly influenced by several environmental factors such as temperature, $\mathrm{pH}$, dissolved oxygen, alkalinity and TSS. The temperature value was in a constant state during culture period.

The average temperature in this study was still within the good condition for eel growth $\left(28.5-30.0^{\circ} \mathrm{C}\right)$. According to $\operatorname{KKP}(2011)$, the optimal temperature range for eel is $27-31^{\circ} \mathrm{C}$, which was confirmed by the study result of Luo et al (2013) that eel was able to grow properlyat temperature of $28-33^{\circ} \mathrm{C}$. The value of $\mathrm{pH}$ during observation period was between the range of $7.1-7.8$, this value was still within the optimum range for eel growth, namely $6.0-8.0$ (Tseng \& Wu, 2004), 7.0 - 8.0 (KKP, 2011).

Dissolved oxygen during the research ranged of $4.3-6.1 \mathrm{mgL}^{-1}$, this value was within the tolerance range for eel growth, that is $>4$ $\mathrm{mgL}^{-1}$ (KKP, 2011), while according to Herianti
(2005), dissolved oxygen for eel growth amounted to $>3 \mathrm{mgL}^{-1}$. Dissolved oxygen also has the function to break down organic matter into inorganic nutrient to be further used by plants. Alkalinity during eel culture had a range of $46-105 \mathrm{mgL}^{-1}$, which was also still within the tolerance limit in eel culture. Study result of Chaudhary \& Pillai (2008)mentioned that optimal alkalinity for eel growth ranged of 58 $123 \mathrm{mgL}^{-1}$. The value of TSS during observation had a range from $1.2-3.94 \mathrm{mgL}^{-1}$.

In the control treatment, TSS value was higher than the treatments with aquatic plants, because there was not filtration system of waste load from in the culture medium. The range of TSS value in this study was still appropriate value for eel, because in fish culture the value of TSS should be $<100 \mathrm{mg} \mathrm{L}^{-}$ ${ }^{1}$ (Palero, 2010). The value of TSS is closely related to water turbidity. The higher value of TSS leads to high turbidity of waters. Turbidity 
is affected by the existence of organic matter, inorganic matter, and other suspended or dissolved material (Khalil et al, 2016).

Aquaculture activity produces organic matter and nutrient in substantial quantity. In general, most of the nitrogen waste $(60-90 \%)$ is in the form of soluble form (particularly ammonia), while it is $25-85 \%$ for phosphorus (Van Rijn 2012). In this study, ammonia was measured in the form of total ammonia nitrogen (TAN). The concentration of TAN, $\mathrm{NO}_{2}$, and $\mathrm{NO}_{3}$ in control was higher than that in treatments (with aquatic plants) since the waste from eel culture in control was not remediated. The range of TAN, $\mathrm{NO}_{2}$ and $\mathrm{NO}_{3}$ in this research was 0.12-0.23 $\mathrm{mgL}^{-1} ; 0.011-0.089$ $\mathrm{mgL}^{-1}$; and 13.31-53.14 $\mathrm{mgL}^{-1}$, respectively (Table 1), which was lower compared to the study conducted by Akinbille et al (2013)who used Eichhornia crassipes and Pistia stratiotesas remediation agent with TAN, $\mathrm{NH}_{3}$, and $\mathrm{NH}_{4}$ value obtained of $1.34 \mathrm{mgL}^{-1} ; 1.79$ $\mathrm{mgL}^{-1} ; 0.14 \mathrm{mgL}^{-1} ; 0.2 \mathrm{mgL}^{-1} ; 0.13 \mathrm{mgL}^{-1}$; and $0.22 \mathrm{mgL}^{-1}$, respectively. Plants in aquaponics system utilize ammonium as the main source of inorganic nutrient through plant roots (Endut et al. 2011).

Phosphorus is one of the major nutrients required by plants (Salisbury and Ross 1995). Orthophosphate $\left(\mathrm{PO}_{4}\right)$ is inorganic compound dissolved in water and can be directly absorbed by plants (Vaillant et al, 2004). Orthophosphate is not toxic to fish. However, high phosphorus content in waters may trigger the growth of algae, resulting in algae bloomingwhich leads to oxygen depletion and mass death of fish. The concentration of orthophosphate in this study ranged from 1.07-8.79 $\mathrm{mgL}^{-1}$. Tolerance for orthophosphate concentration in eel culture ranges of $150 \mathrm{mg} / \mathrm{L}$ (Suzuki et al, 2003).

Statistical analysis result for nutrient removal efficiency during culture period indicated significantly different result between treatments. Treatment P2 (E.palaefolius) resulted in the highest value of nutrient removal efficiency (TAN, $\mathrm{NO}_{2}, \mathrm{NO}_{3}$, and $\mathrm{PO}_{4}$ ). More complete data are presented in Table 2.

Table 2. The average of nutrient removal efficiency (\%)

\begin{tabular}{cccc}
\hline Parameter & P1 (E. amazonicus) & P2 (E. palaefolius) & P3 (Without plant) \\
\hline $\mathrm{TAN}(\%)$ & $22.19 \pm 1.94^{\mathrm{b}}$ & $27.10 \pm 2.42^{\mathrm{c}}$ & $2.18 \pm 0.19^{\mathrm{a}}$ \\
$\mathrm{NO}_{2}(\%)$ & $29.40 \pm 3.95^{\mathrm{a}}$ & $45.03 \pm 9.77^{\mathrm{b}}$ & $18.15 \pm 4.83^{\mathrm{a}}$ \\
$\mathrm{NO}_{3}(\%)$ & $11.95 \pm 1.24^{\mathrm{b}}$ & $20.94 \pm 1.29^{\mathrm{c}}$ & $1.85 \pm 1.9^{\mathrm{a}}$ \\
$\mathrm{PO}_{4}(\%)$ & $4.75 \pm 3.16^{\mathrm{a}}$ & $14.19 \pm 3.05^{\mathrm{b}}$ & $3.96 \pm 3.48^{\mathrm{a}}$ \\
\hline
\end{tabular}

Different superscriptlettersshow significantly different effect between treatments $(P<0.05)$

There is a trend of nutrient removal efficiency every two weeks in each treatment (Figure 1). The efficiency of $\mathrm{NO}_{2}$ and $\mathrm{PO}_{4}$ removal in all treatments tended to decrease every 2 weeks. The efficiency of $\mathrm{NO}_{3}$ removal tended to decline for all treatments, except for a treatment without aquatic plant in week $6^{\text {th }}$. There was an increasing value of nutrient removal efficiency in control treatment. 


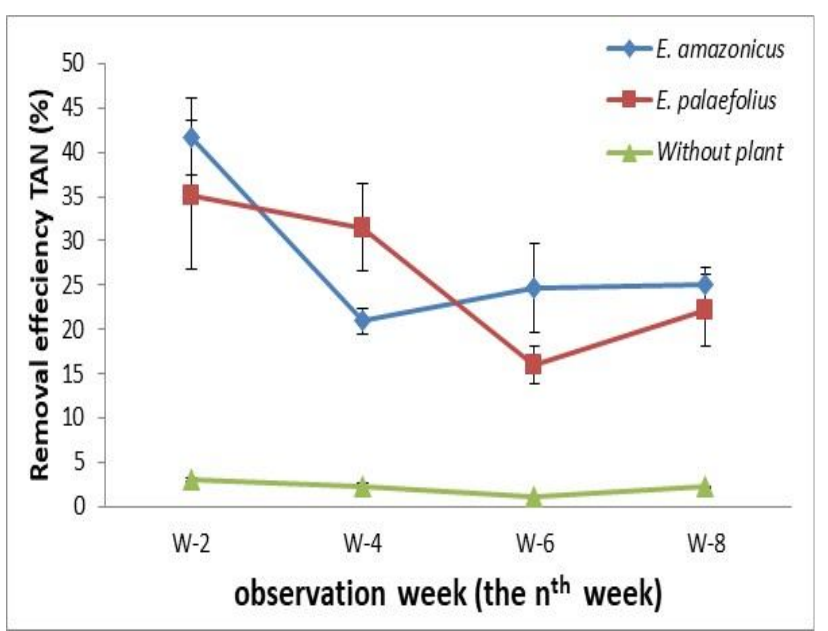

(a)



(c)

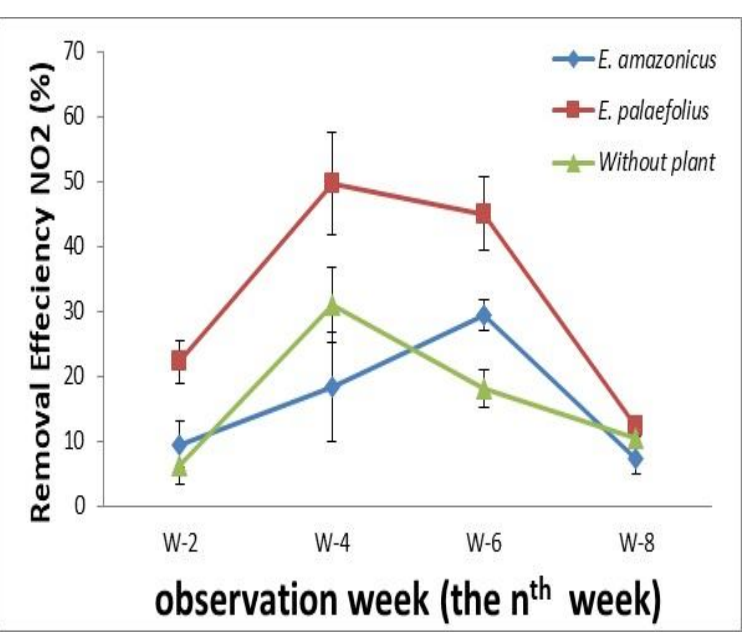

(b)

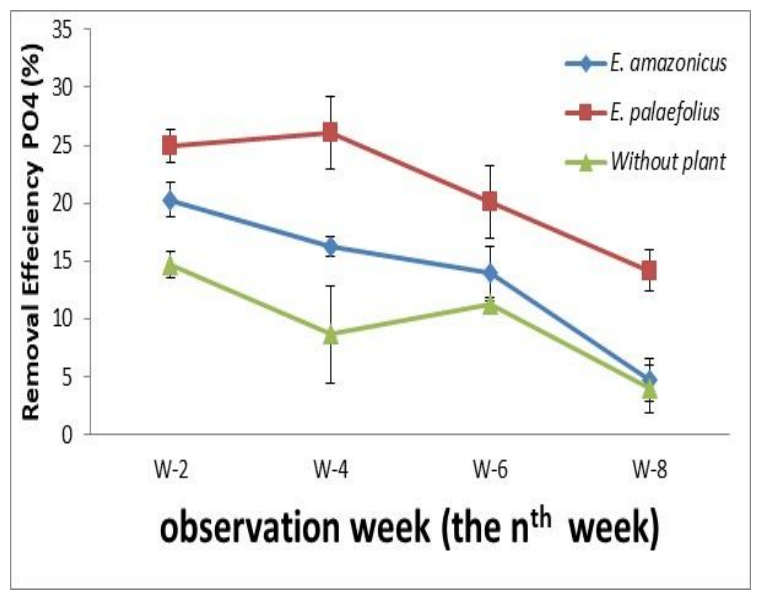

(d)

Figure 1. Removal efficiency (\%) TAN (a), $\mathrm{NO}_{2}$ (b), $\mathrm{NO}_{3}$ (c) and $\mathrm{PO}_{4}(\mathrm{~d})$.

Change in nutrient removal efficiency in the three treatments showed that each plant has different ability to utilize nutrient. The ability of $E$. palaefoliusin removing nutrient from eel culture wastewater was higher than that of $E$. amazonicus. It was found that $E$. palaefoliuswas able to removethenutrient of TAN of $35.13 \%$ in week- $2, \mathrm{NO}_{2}$ of $49.65 \%$ in week-4, $\mathrm{NO}_{3}$ of $30.31 \%$ in week-2, and $\mathrm{PO}_{4}$ of $26.13 \%$ in week-4. Compared to the study conducted by Chrismada and Mardiati (2011), it was found that $\mathrm{L}$. perpusilla hasabsorbtive capacity of $3.9 \mathrm{mg} \mathrm{NO}_{3} \mathrm{~m}^{-2}$ day $^{-1}$ and $6.7 \mathrm{mg} \mathrm{PO}_{4}$ $\mathrm{m}^{-2} \mathrm{day}^{-1}$ in water media originated fromSaguling Dam in day-3 of study with removal rate of $\mathrm{N}$ $\mathrm{NO}_{3}$ of $74.05 \%$ and $\mathrm{P}-\mathrm{PO}_{4}$ of $73.36 \%$. Result of this study showed lower value, yet the concentration of TAN, $\quad \mathrm{NO}_{2}, \quad \mathrm{NO}_{3}$, and
$\mathrm{PO}_{4}$ obtained was still within the optimum range for eel to live.

\section{Growth performance of eel}

Based on Table 3, specific growth rate (SGR) ranged of $0.94 \%-1.19 \%$. The range of feed conversion rate (FCR) was 1.57-3.91. Protein retention had a range of $18.88 \%$ $41.12 \%$ and lipid retention ranged of $29.27 \%$ $47.31 \%$. Survival rate of all treatments was $100 \%$. Result of statistical analysis showed that significantly different effect was found between treatments in all parameters. The use of $E$. palaefoliusplant resulted in highest value of SGR, protein retention, and lipid retention of $1.19 \pm 0.18 \%$; $41.12 \pm 3.51 \%$; and $47.31 \pm 6.65 \%$, respectively, compared with E.amazonicusplant and control. 
Table 3. Growth performance of eel

\begin{tabular}{cccc}
\hline Parameter & P1 (E. amazonicus) & P2 (E. palaefolius) & P3 (Without plant) \\
\hline SR (\%) & 100 & 100 & 100 \\
SGR (\%) & $0.94 \pm 0.21^{\mathrm{ab}}$ & $1.19 \pm 0.18^{\mathrm{b}}$ & $0.65 \pm 0.30^{\mathrm{a}}$ \\
FCR & $2.09 \pm 0.67^{\mathrm{ab}}$ & $1.57 \pm 0.30^{\mathrm{a}}$ & $3.91 \pm 1.09^{\mathrm{c}}$ \\
Protein Retention (\%) & $37.18 \pm 4.01^{\mathrm{b}}$ & $41.12 \pm 3.51^{\mathrm{b}}$ & $18.88 \pm 2.69^{\mathrm{a}}$ \\
Lipid Retention (\%) & $42.47 \pm 7.10^{\mathrm{b}}$ & $47.31 \pm 6.65^{\mathrm{b}}$ & $29.27 \pm 2.44^{\mathrm{a}}$ \\
\hline Different superscript letters show significantly different effect between treatments $(\mathrm{P}<0.05)$
\end{tabular}

Based on the data of eel growth performance (Table 3), the use of aquatic plant as phytoremediator was able to decrease FCR as well as increase SGR, protein retention, and lipid retention. This finding showed that the use of aquatic plant ( $E$. amazonicus dan $E$. palaefolius) in this study did not create inhibitory effect on survival rate and the growth of eel. Increasing growth performance of eel indicated that the role of aquatic plant in phytoremediation is necessary since the environment in which the fish live is improving as seen from the optimum value of water quality parameter during culture period (Table 1). Study result of El-Shafai et al (2007) proved that the application combination of recirculating system and Lemna gibba aquatic plant was able to increase the growth and decrease FCR in Tilapia culture. Similarly, result of study performed by Ghaly et al (2004); Endut et al (2011); Effendi et al (2015), by using aquatic plant as phytoremediator in recirculating system was found to increase the growth performance of the commodity cultured.

\section{Growth performance of plants}

During culture period of 60 days, freshwater aquarium plants grew well. The growth performance of aquatic plants was seen from the weight gain, daily growth rate, nitrogen retention, and phosphorus retention in plant tissue. Data of aquatic plant growth are presented in Table 4.

Table 4. Growth performance of plants during 60 days of culture

\begin{tabular}{ccc}
\hline Parameter & P1 (E. amazonicus) & P2 (E. palaefolius) \\
\hline Weight gain (gram) & $9.33 \pm 2.52$ & $32.67 \pm 8.96$ \\
Daily growth rate (g/day) & $0.16 \pm 0.04$ & $0.54 \pm 0.15$ \\
N retention (\%) & $2.59 \pm 1.22$ & $21.47 \pm 2.97$ \\
P retention (\%) & $3.97 \pm 0.84$ & $6.36 \pm 1.08$ \\
\hline
\end{tabular}


The success of phytoremediation system cannot be separated from the growth of plant as phytoremediation agent. During the observation period, the growth of aquatic plants in phytoremediation system showed positive responseas indicated by the increasing biomass growth, nitrogen retention, and phosphorus retention in plants. Aquatic plants used in this study were found to have the ability to utilize eel culture wastewater as nutrient source for growth. This statement was confirmed by the occurrence of nutrient removal by plants every observation period (2 weeks) (Figure 1). The growth of $E$. palaefoliuswas faster than that of $E$. amazonicus, as well as its nitrogen and phosphorus retentions which were also higher.

\section{Conclusion}

Treatment using aquatic plant $E$. amazonicusand and E.palaefoliusas phytoremediator highly affected the declining concentration of TAN, $\mathrm{NO}_{2}, \mathrm{NO}_{3}$, and $\mathrm{PO}_{4}$ in eel culture wastewater. The ability of $E$. palaefoliusin utilizing the nutrient of fish culture waste was found to be better than that of $E$. amazonicus. The growth performance of eel maintained with phytoremediator $E$. amazonicusand E. palaefoliuswas better than the growth of eel treated without aquatic plants.

\section{Acknowledgments}

This study was financially supported by the Ministry of Research, Technology and Higher Education, Indonesia in Beasiswa Pendidikan Pascasarjana Dalam Negeri (BPPDN). Thank you for DRPM General Directorate of Reinforcement Improvement and Research for research grant aid in the form of Doctoral Dissertation Grant (PDD) 2018.

\section{References}

[APHA] American Public Health Association. 2006. Standard Methods for the Examination of the Water and Wastewater, $22^{\text {nd }}$ ed. American Public Health Association, Washington, DC.

Affandi R, Budiardi T, Wahju RI, Taurusman A. 2013. Pemeliharaan Ikan Sidat dengan Sistem Air Bersirkulasi (Eel Rearing in Water Recirculation System). Jurnal IImu Pertanian Indonesia (JIPI) 18,55 60.

Akinbile CO, Yusoff MS. 2012. Assessing water hyacinth (Eichhornia crassopes) and lettuce (Pistia stratiotes) effectiveness in aquaculture wastewater treatment. International Journal of Phytoremediation 14, 201-211.

Brune DE, Schwartz G, Eversole AG, Coller JA, Schwedler TE. 2003. Intensification of pond aquaculture and high rate photosynthetic systems. Aquaculture Engineering 28, 65-86.

Bureau DP, Hua K. 2011. Toward effective nutritional management of waste outputs in aquaculture, with particular reference to salmonid aquaculture operations. Review article. Journal Aquaculture Research 41, 777-792.

Chaudhary R, Pillai RS. 2008. Studies on the physico-chemical parameters of Sasthamcottah lake (India) with reference to suitability for aquaculture. Journal of Environmental Research and Development 2, 402-405.

Chrismadha T, Mardayati Y. 2012. Uji Tumbuh Lemna (Lemna Perpusilla orr.) dan Penyerapan Unsur Hara dalam Media Air Waduk Saguling. Oseanologi dan Limnologi di Indonesia 38, 369-376.

Crab R, Avnimelech Y, Defoirdt T, Bossier P, Venstraete W. 2007. Nitrogen removal technique in aquaculture for a sustainable production. Aquaculture 277, 125-137.

Davidson J, Good C, Barrows FT, Welsh C. 2013. Comparing the effects of feeding a grain or a fish meal based diet on water quality, waste production, and rainbow trout Oncorrhynchus mykiss performance within low exchange water recirculating aquaculture systems. Aquaculture Engineering 52, 45-57.

Davidson J, Barrows FT, Kenney PB, Good C,Schroyer K, Steven T. Summerfelt. 2016. Effects of feeding a fishmeal-free versus a fishmeal-based diet onpostsmolt Atlantic salmon Salmo salar performance, water quality, and waste production in recirculation aquaculture systems. Aquacultural Engineering 74, 38-51.

Ebeling JM, Timmons MB, Bisogni JJ. 2006. Engineering analysis of the stoichiometry of photoautotrophic, autotrophic, and heterotrophic removal of ammonia-nitrogen in aquaculture systems. Aquaculture 257, 346- 358.

Effendi H, Utomo BA, Darmawangsa GM. 2015. Phytoremediation of freshwater 
Crayfish (Cherax quadricaarinatus) culture wastewater with spinach (Ipomoea aquatica) in aquaponic system. Aquaculture, Aquarium, Conservation and Legislation International, Journal of the Bioflux Society 8, 421-430.

El-Shafai SA, El-Gohary FA, Naser FA, Van der Steen P, Gijzen HJ. 2007. Nitrogen recovery in an integrated system for wastewater treatment and tilapia production. Environmentalist 27, 287302.

Endut A, Jusoh A, Ali N, Nik WBW. 2011. Nutrient removal from aquaculture wastewater by vegetable production in aquaponic recirculation System. Desalination and Water Treatment. 32, 422-430.

Ghaly AE, Kamal M, Mahmoud NS. 2004. Phytoremediation of aquaculture wastewater for water recycling and production of fish feed. Environmentallnternational, 31, 1-13.

Handajani H, Widanarni, Setiawati M, Budiardi T, Sujono. 2018. Evaluation of digestibility and ammonia excretion of fish meal and fish silage fed to juvenile Indonesian shortfin eel (Anguilla bicolor). AACL Bioflux 11, 495-504.

Harianto E, Budiardi T, Sudrajat O. 2014. Growth performance of 7-g Anguilla bicolor bicolor at different density Jurnal Akuakultur Indonesia 13, 120-131.

Herianti I. 2005. Rekayasa lingkungan untuk memacu perkembangan ovarium ikan sidat Anguilla bicolor. Jurnal Oseanologi Limnologi Indonesia 37, 25-41.

Herniwati, Priatmadi JB, Yanuwiadi B, Soemarno, 2005. Water Plants Characteristic for Phytoremediation of Acid Mine Drainage Passive Treatment. International Journal of Basic and Applied Sciences B(06): 136706-2525.

Khalil M, Ezraneti R, Jannatiah, Hajar S. 2016. Penggunaan Keong Bakau Telescopium sp (Gastropoda: Potamididae) dan Siput Bakau Cerithidea sp (Gastropoda: Potamididae) Sebagai Biofilter terhadap Limbah Budidaya lkan Bandeng (Chanos chanos). Omni-Akuatika 12, 88 - 97.

KKP [Kementerian Kelautan dan Perikanan]. 2011. Panduan Budidaya Ikan Sidat.
Jakarta, Indonesia: Pusat penyuluhan kelautan dan perikanan, KKP RI.

Luo M, Guan R, Li Z, Jin H. 2013. The effects of water temperature on the survival, feeding, and growth of the juveniles of Anguilla marmorata and Anguilla bicolor pacifica. Aquaculture 400-401, 61-64.

Madhurina M, Bidisha M, Shekhar MM, Sankar C, Amitawa G, Arunabha M, 2014. Study on the Phytoremediation Potential Wastewater A Case Study in Indian Context. International Research Journal of Environment Sciences 3, 83-89.

Mkandawire M, Dudel EG, 2007. Are Lemna spp. Effective Phytoremediation Agents. Journal Bioremediation, Biodiversity, and Bioavailability Global Science Books 1, 56-71.

Muangkeow B, Ikejima K, Powtongsook S, Yi Y. 2007. Effects of white shrimp, Litopenaeus vannamei (Boone), and Nile tilapia, Oreochromis niloticus L., stocking density on growth, nutrient conversion rate and economic return in integrated closed recirculation system. Aquaculture 269, 363-376.

Paz-Alberto AM, Sigua GC. 2013. Phytoremediation: a green technology to remove enviromental pollutans. American Journal of Climate Change. 2, 71-86.

Pelero LW. 2010. Review: In situ and Bioremediation of Organic Pollutants in Aquatic Sediments. Journal of Hazardous Materials 177, 81-89.

RahmanMA, Hasegawa H., 2011. Aquatic Arsenic: Phytoremediation Using Floating Macrophytes. Journal Chemosphere 83, 633-646.

Salisbury FB, Ross CW. 1995. Fisiologi Tumbuhan. Jilid ke-1. Lukman DR, Sumaryono, Penerjemah. Bandung (ID): ITB Pr. Terjemahan dari: Plant Physiology 4th edition.

Suzuki Y,Maruyama T, Numata $H$, Sato $H$, Asakawa M. 2003. Performance of a closed recirculating system with foam separation, nitrification and denitrification units for intensive culture of eel: towards zero emission. Aquacultural Engineering 29, 165-182.

Syahputra R. 2005. Fitoremediasi Logam Cu dan Zn dengan Tanaman Eceng Gondok (Eichhornia crassipe (Mart.) Solms). Jurnal Logika 2. 
Tseng KF, Wu KL. 2004. The ammonia removal cycle for a submerged biofilter used in a recirculating eel culture system. Aquacultural Engineering 31, 17-30.

Vaillant $N$, Monnet $F$, Sallanon $H$, Coudret A, Hitmi A. 2004. Use of commercial plant species in a hydroponic system to treat domestic wastewaters. Journal of Environmental Quality 33, 695-702.

Van Rijn J. 2012. Waste treatment in recirculating aquaculture systems. Aquacultural Engineering 53 49-56.

Zhou Y,Yang $\mathrm{H}$, Hu H, Liu $\mathrm{Y}$, Mao $\mathrm{Y}$, Zhou $\mathrm{H}$, Xu X, Zhang F. 2006. Bioremidiation potential of the macroalga Gracilaria lemaneiformis (Rhodophyta) integrated into fed fish culture in coastal waters of north China. Aquaculture 252, 264-276 